\title{
PENGEMBANGAN MODEL EVALUASI SITUS WEB DESTINATION MARKETING ORGANIZATION DARI PERSPEKTIF EFEKTIVITAS DAN DESAIN ANTARMUKA PERANGKAT SELULER
}

\author{
Fadli Suandi ${ }^{1}$, Wing Wahyu Winarno ${ }^{2}$ \\ Magister Informatika \\ Universitas Islam Indonesia \\ Jl. Kaliurang Km. 14,5 Sleman, Daerah Istimewa Yogyakarta \\ fadlisuandi@gmail.com¹, wingwahyuwinarno@gmail.com²
}

\begin{abstract}
ABSTRAK
Pemanfaatan situs web sebagai sarana pemasaran pariwisata telah diadopsi oleh berbagai Destination Marketing Organization (DMO) di seluruh dunia, namun situs web yang telah diimplementasi harus dievaluasi untuk melihat apakah situs web tersebut efektif untuk menunjang kegiatan promosi pariwisata. Penelitian sebelumnya telah mengembangkan model evaluasi ICTRT (information, communication, transaction, relationship, technical merit) untuk mengevaluasi efektivitas situs web DMO. Namun model evaluasi ICTRT dikembangkan hanya untuk mengevaluasi situs web konvensional yang biasa dilihat pada perangkat komputer desktop, sehingga kurang tepat digunakan untuk mengevaluasi situs web khusus tampilan seluler. Penelitian ini bertujuan untuk mengembangkan model ICTRT yang dapat digunakan untuk mengevaluasi situs web DMO yang didesain untuk tampilan perangkat seluler, yang diberi nama model ICTRT for mobile. Model ICTRT for mobile selanjutnya digunakan untuk mengevaluasi efektivitas situs web DMO negara Indonesia pada tampilan perangkat seluler. Hasil yang peroleh bahwa situs web DMO negara Indonesia pada tampilan perangkat seluler masih menunjukkan efektivitas yang kurang memuaskan khususnya pada dimensi transaction dan relationship.
\end{abstract}

Kata kunci: Destination Marketing Organization, Model evaluasi, Pariwisata, Situs web

\begin{abstract}
The utilization of website as a means of tourism marketing has been adopted by various Destination Marketing Organization (DMO) around the world. However, websites that have been implemented should be evaluated to check whether the website is effective to support the promotion of tourism activities. Previous research have developed an evaluation model ICTRT (information, communication, transaction, relationship, technical merit) to evaluate the effectiveness of DMO website. Nevertheless, ICTRT evaluation model was developed only for evaluating conventional website which is normally viewed on desktop computer device, making it less appropriate to be used in evaluating specific mobile display website. This study aims to develop ICTRT model that can be used to evaluate DMO website designed for mobile device display, which is called ICTRT model for mobile. ICTRT model for mobile is then used to evaluate the effectiveness of Indonesia's DMO website on mobile device display. The result obtained that Indonesia's DMO website on mobile device display still shows less effectiveness, especially in the transaction and relationship domain.
\end{abstract}

Keywords: Destination Marketing Organization, Evaluation model, Tourism, Website 


\section{PENDAHULUAN}

Pemanfaatan internet sebagai media pemasaran pariwisata salah satunya melalui situs web $E$ commerce yang kemudian disebut dengan $E$ Tourism [1]. Untuk mengetahui apakah situs web $E$ Tourism tersebut sudah efektif sebagai media promosi, dibutuhkan suatu metode evaluasi yang dapat mengukur efektivitas tersebut. Evaluasi situs web menjadi penting karena dapat membantu organisasi melacak kinerja situs web mereka pada periode waktu tertentu, serta memberikan kemudahan melakukan perbandingan kinerja situs web yang mereka miliki terhadap situs web pesaing lainnya [2].

E-tourism selanjutnya berkembang pada ranah Destination Marketing Organization (DMO). Menurut World Tourism Organization DMO adalah organisasi yang bertanggung jawab untuk mengelola dan atau memasarkan destinasi wisata yang terbagi ke dalam beberapa kelompok seperti Badan Pariwisata Nasional, regional dan lokal [3]. DMO Memiliki manfaat sebagai media yang penting bagi wisatawan, pengelola bisnis pariwisata hingga pemerintah untuk membantu penyebaran informasi potensi pariwisata yang ada pada negara tersebut.

Vitalnya pengelolaan situs web dalam perkembangan bisnis pariwisata membuat banyak peneliti yang tertarik untuk mengembangkan framework untuk mengevaluasi situs web DMO, tetapi belum ada model evaluasi baku yang disepakati untuk mengevaluasinya [4]. Peneliti mencurahkan upaya penelitian di bidang evaluasi situs web pariwisata untuk menemukan inovasi dan membantu praktisi industri pariwisata menerapkan temuan mereka. Dengan demikian, terdapat hubungan yang kuat antara temuan akademik dan praktik industri pariwisata di bidang ini. Dengan menerapkan temuan tersebut, praktisi pariwisata dan perhotelan dapat meningkatkan praktek operasional bisnis mereka [5].

Evaluasi situs web mengalami perkembangan yang pesat yang ditandai dengan lahirnya model evaluasi oleh para peneliti. Model evaluasi situs web yang banyak diadopsi oleh beberapa peneliti saat ini adalah model evaluasi berdasarkan perspektif efektivitas. Model evaluasi berdasarkan efektivitas adalah model yang mengevaluasi situs web tidak hanya menilai situs web berdasarkan fitur, tetapi juga menilai apakah fitur yang terdapat pada suatu situs web sudah diimplementasi dan berfungsi dengan baik.

Li dan Wang [6] melakukan penelitian tentang evaluasi pada efektivitas situs web DMO. Penelitian tersebut mengevaluasi dari perspektif efektivitas situs web yang terbagi dalam lima kategori, yaitu: information dimension (dimensi informasi), communication dimension (dimensi komunikasi), transaction dimension (dimensi transaksi), relationship dimension (dimensi hubungan) dan technical merit dimension (dimensi teknis). Kelima aspek tersebut kemudian diuji untuk mengevaluasi 50 situs web DMO di Amerika serikat. Model tersebut kemudian dikenal dengan model evaluasi ICTRT (Information, Communication, Transaction, Relationship, Technical merit). Model yang dikembangkan oleh Li dan Wang berhasil digunakan untuk mengevaluasi situs web E-tourism. Meskipun model ICTRT sudah cukup baik mengevaluasi efektivitas suatu situs web, tetapi masih memungkinkan untuk dikembangkan dengan memasukkan aspek evaluasi dari sudut pandang yang lain, seperti mempertimbangkan konsep evaluasi desain situs web khusus pada perangkat seluler.

Evaluasi desain situs web khusus untuk perangkat seluler menjadi penting karena berdasarkan data survey yang dilakukan oleh APJII (Asosiasi Penyelenggara Jasa Internet Indonesia) pada tahun 2014, perangkat seluler menjadi perangkat yang paling banyak digunakan untuk mengakses internet di Indonesia dengan total persentasi $85 \%$ [7], sehingga evaluasi dari aspek desain antarmuka situs web E-Tourism pada perangkat seluler perlu dilakukan.

Evaluasi situs web khusus pada perangkat seluler telah dilakukan oleh Yu dan Kong [8]. Mereka melakukan penelitian tentang pengaruh desain antarmuka situs web pada perangkat seluler terhadap usability pengunjung situs web berita. Mereka berhasil membuktikan bahwa desain antarmuka situs web pada perangkat seluler memiliki pengaruh yang signifikan terhadap ease of use (kemudahaan penggunaan), reading time (durasi membaca) dan overall reading experience (pengalaman membaca secara keseluruhan).

Penelitian lain yang membahas tentang desain antarmuka pada perangkat seluler dilakukan oleh Jones dan kawan-kawan [9]. Mereka menemukan dua panduan penting untuk pengembangan desain situs web untuk perangkat seluer, yaitu desain situs web untuk perangkat dengan layar kecil haruslah memiliki fitur pencarian dan memiliki fitur menu yang didesain untuk mengurang kegiatan scrolling pada halaman situs web. Beberapa peneliti sepakat menyimpulkan bahwa desain situs web pada perangkat seluler harus bersifat responsif. Desain halaman situs web yang responsif adalah halaman situs web yang kompatibel dengan berbagai perangkat seluler, bukan dikembangkan khusus hanya pada perangkat tertentu saja [10].

Penelitian-penelitan yang membahas tentang desain situs web pada perangkat seluler menjadi masukan untuk pengembangan model evaluasi pada situs web DMO. Model yang diusulkan pada penelitian ini merupakan pengembangan model evaluasi ICTRT yang digunakan oleh Li dan Wang mengevaluasi situs web DMO, dengan penambahan atribut evaluasi pada dimensi technical merit berdasarkan desain antarmuka pada perangkat seluler. Tambahan atribut evaluasi tersebut akan 
dilebur ke dalam model ICTRT sehingga perspektif evaluasi situs web DMO menjadi lebih luas.

Selanjutnya model evaluasi yang dikembangkan pada penelitian ini akan diujikan untuk mengevaluasi situs web DMO yang ada di Indonesia. Dari pengembangan model evaluasi ini diharapkan nantinya bisa digunakan oleh pengelola situs web untuk mengevaluasi kembali situs web DMO yang telah mereka miliki. Model evaluasi ini juga dapat dijadikan rujukan pedoman bagi para pengelola situs web DMO di negara lain yang tertarik untuk mengembangkan situs web DMO. Pedoman tersebut bermanfaat agar situs web DMO yang mereka miliki dapat membantu promosi bisnis pariwisata yang mereka kembangkan menjadi lebih maksimal.

\section{TINJAUAN PUSTAKA \\ Pengembangan Model Evaluasi}

Model evaluasi adalah sebuah alat yang digunakan untuk mengukur dan menilai suatu objek. Lundberg [11] menyebutkan bahwa model evaluasi dapat dikelompokkan dengan berbagai pendekatan, namun secara umum terbagi kepada tiga kategori yaitu result model, actor model dan economi model.

Result model adalah model yang memiliki fokus untuk menilai hasil dari sebuah kinerja, program atau organisasi. Model evaluasi ini juga memberikan informasi apakah tujuan utama dari kinerja tersebut sudah tercapai atau belum tercapai. Actor model adalah model evaluasi yang mengedepankan aktor seperti stakeholder dan pengguna sebagai penentu kriteria penilaian. Pendekatan model evaluasi seperti ini sering dijumpai pada evaluasi program hingga teknologi yang berorientasi kepada stakeholder dan pengguna. Terakhir adalah economic model yang menguji dan menilai apakah produktivitas, efektivitas dan utilitas dari suatu objek telah sesuai dengan biaya yang telah dikeluarkan.

Pengembangan model evaluasi selanjutnya dilakukan oleh para peneliti sesuai dengan pendekatan yang berbeda-beda. Metodologi yang digunakan juga beragam, salah satu metode yang banyak diadopsi untuk pengembangan model adalah metode reseach \& development ( $\mathrm{R} \& \mathrm{D})$. Metode $\mathrm{R} \& \mathrm{D}$ diperkenalkan oleh Richey dan Klein pada tahun 2009 [12].

Richey dan Klein menyebutkan perancangan dan penelitian pengembangan dilakukan dengan analisis dari tahap awal hingga akhir dengan mencakup proses perancangan, produksi dan evaluasi. Perancangan adalah proses awal berupa analisis kebutuhan dengan melakukan kajian pustaka atau studi literatur. Produksi adalah langkah selajutnya berupa kegiatan membuat suatu produk/model berdasarkan rancangan yang telah ditentukan. Evaluasi adalah langkah terakhir berupa kegiatan menguji ataupun menilai apakah produk/model yang telah dibuat tersebut telah memenuhi kriteria yang diinginkan [12].

Model R\&D terbagi pada empat macam proses pengembangan model yang memiliki perbedaan tingkat kesulitan, yaitu:

1. Meneliti tanpa menguji (tidak membuat dan tidak menguji produk/model)

2. Menguji tanpa meneliti (menguji validitas produk/model yang telah ada)

3. Meneliti dan menguji dalam upaya mengembangkan produk/model yang telah ada

4. Meneliti dan menguji untuk menciptakan produk/model baru.

\section{Evaluasi situs web $E$-Tourism}

Evaluasi situs web diprakarsai oleh $\mathrm{Lu}$ dan Yeung [13]. Mereka mengenalkan sebuah framework yang digunakan untuk mengevaluasi performa situs web dari segi fungsional dan kegunaannya. Walaupun framework tersebut dapat digunakan untuk mengevaluasi situs web, tetapi masih belum sempurna. Ip, Law dan Lee [5] merangkum perkembangan evaluasi situs web pariwisata dan perhotelan dari tahun 1996 hingga 2009. Dari hasil penelitian yang mereka lakukan, disimpulkan bahwa evaluasi situs web terbagi atas tiga kelompok, yaitu:

1. Evaluasi berdasarkan fase

2. Evaluasi berdasarkan fitur

3. Evaluasi berdasarkan fitur dan efektivitas

Dari tiga kelompok evaluasi tersebut kemudian dibagi ke dalam beberapa kelompok evaluasi, berikut gambaran kelompok evaluasi situs web yang lebih rinci dapat dilihat pada Gambar 1.

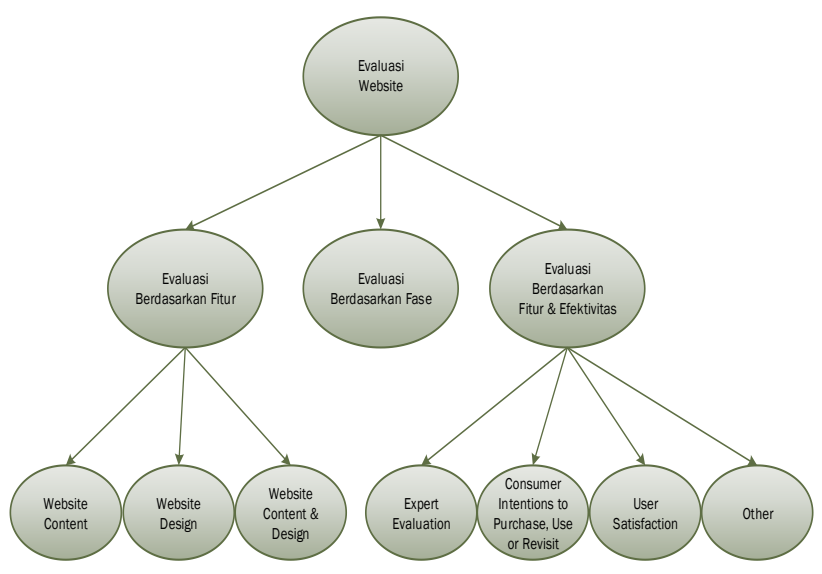

Gambar 1. Pengelompokan Evaluasi Situs web $E$ Tourism [5]

\section{Evaluasi Berdasarkan Fitur dan Efektivitas}

Evaluasi situs web berdasarkan fitur dan efektivitas diklasifikasi pada empat kategori dimensi yaitu: expert evaluation, consumer intentions to purchase, use, or revisit, user satisfaction dan dimensi yang lain. Dimensi expert evaluation adalah evaluasi situs web dengan melibatkan pakar sistem 
informasi maupun manager bisnis untuk mengukur efektivitas situs web.

Penelitian yang dilakukan oleh Li dan Wang [6] adalah evaluasi yang termasuk kategori expert evaluation untuk menilai efektivitas situs web. Mereka mengukur efektivitas 50 situs web $E$ Tourism di Amerika berdasarkan perspektif efektivitas yang terdiri atas lima dimensi, yaitu: information dimension, communication dimension, transaction dimension, relationship dimension dan technical merit dimension. Model evaluasi yang mereka kembangkan tersebut bernama ICTRT (Information, Communication, Transaction, Relationship, Technical) model seperti yang terlihat pada Gambar 2. Model ICTRT terdiri dari 47 atribut evaluasi yang terbagi pada 19 atribut pada dimensi informasi, 10 atribut pada dimensi komunikasi, 5 atribut pada dimensi transaksi, 6 atribut pada dimensi hubungan dan 7 atribut pada dimensi teknis.

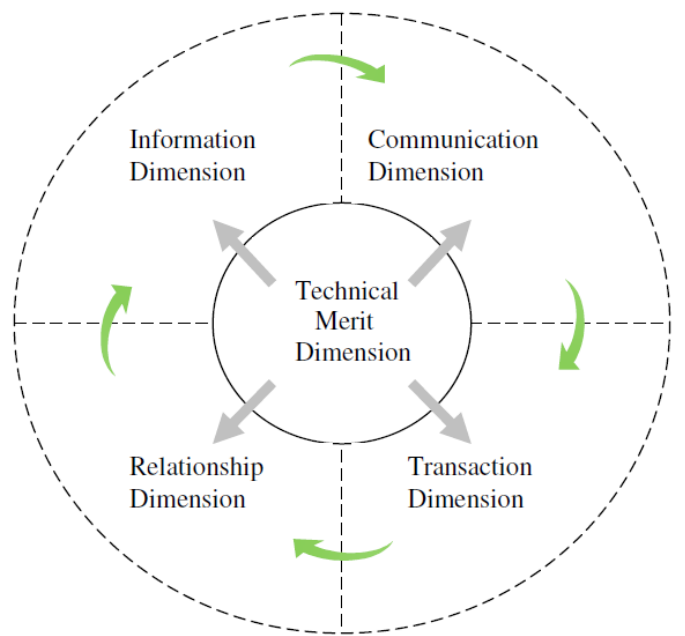

Gambar 2. Model evaluasi situs web ICTRT [14]

Untuk mendapatkan nilai efektivitas suatu atribut situs web, model ICTRT diukur dengan skala likert 5 point yang terbagi pada tiga bagian penilaian yaitu tingkat kepentingan (importance), kompleksitas (complexity) dan performa (performance). Performa fitur situs web dinilai dengan menggunakan skala likert dalam skala nilai 5 $(1=$ sangat buruk, $5=$ sangat baik). Tingkat kepentingaan adalah penilaian seberapa penting fitur situs web yang dievaluasi dengan menggunakan skala likert dalam skala nilai $5(1=$ tidak penting, 5 $=$ sangat penting). Kompleksitas adalah peilaian seberapa rumit dalam mengimplementasi fitur situs web tersebut dengan menggunakan skala likert dalam skala nilai $5 \quad(1=$ sangat mudah diimplementasi, $5=$ sangat sulit diimplementasi). Nilai 0 diberikan jika instrumen tersebut tidak terdapat pada situs web. Nilai efektivitas didapatkan dengan rumus sebagai berikut:

\section{Efektivitas $=$ Performa instrumen $\mathrm{x}$ Tingkat kepentingan insturmen}

Perhitungan di atas digunakan untuk menghitung nilai efektivitas pada dimensi information, communication, transaction, relationship dan technical merit. Semakin mendekati angka 5 maka semakin tinggi pula tingkat efektivitas dimensi tersebut. Sebaliknya jika angka evaluasi dimensi mendekati angka 0 , semakin rendah tingkat efektivitasnya. Tabel 1 menampilkan keseluruhan 47 bagian pada model ICTRT.

\section{Evaluasi Desain Situs Web pada Tampilan Perangkat Seluler}

Yu dan Kong [8] adalah peneliti yang memprakarsai penelitian dibidang evaluasi situs web berdasarkan desain antarmuka pada perangkat seluler. Mereka membuktikan bahwa desain antarmuka situs web pada perangkat seluler berpengaruh terhadap usability pengunjung situs web berita. Mereka megembangkan pedoman desain antarmuka situs web berita untuk perangkat seluler. Mereka menemukan bahwa desain situs web dengan desain satu halaman penuh (single-page) lebih difavoritkan daripada situs web dengan banyak halaman dan beranda (home page) situs web dengan desain thumbnail memberikan pengolahan informasi yang lebih baik bagi pengunjung situs web.

Beberapa penelitian yang membahas tentang desain situs web khusus pada perangkat seluler telah dilakukan bahkan sebelum perangkat seluler marak digunakan seperti pada saat ini. Jones dan kawankawan menyimpulkan bahwa desain situs web pada perangkat dengan layar berukuran kecil secara umum terbagi pada dua poin utama. Pertama adalah menyediakan akses pencarian informasi secara langsung yaitu dengan membuat suatu fitur pencarian khusus yang dapat memberikan kemudahan pengunjung situs web dalam mencari informasi. Kedua adalah mengurangi kegiatan scrolling saat mengakses situs web. Kegiatan scrolling saat mengakses situs web menggunakan layar yang kecil dapat dikurangi dengan meletakkan fitur navigasi di menu bar yang bersifat tetap, seperti di bagian atas ataupun samping halaman situs web. Kegiatan scrolling juga dapat dihindari dengan membuat content informasi yang lebih terfokus pada pembahasan tertentu, serta menghindari informasi yang bertele-tele [9].

Desain situs web pada perangkat seluler kemudian disepakati oleh beberapa peneliti yang mengatakan bahwa desain situs web yang bersifat responsif dan dapat menyesuaikan tampilan situs web pada perangkat yang berbeda-beda adalah poin penting yang harus terapkan pada situs web khususnya yang didesain untuk perangkat seluler. Qiu, Zhang dan Huang [15] berpendapat bahwa desain antarmuka situs web untuk perangkat seluler haruslah dapat menyesuaikan dengan ukuran layar perangkat seluler, sehingga seluruh content situs web dapat ditampilkan dengan baik dan kompleksitas navigasi pengguna diminimalkan. 
Situs web responsif berarti bahwa sebuah situs web dapat kompatibel dengan beberapa perangkat dan bukan dikembangkan khusus hanya pada perangkat tertentu saja [10].

Meningkatnya tren browsing menggunaan perangkat seluler memberikan pengaruh yang cukup besar dalam perkembangan teknologi situs web, hingga pada tanggal 21 April 2015 mesin pencari Google secara khusus menambahkan komponen mobile-friendliness sebagai komponen penilaian hasil pencarian pada sebuah situs web [16]. Mobilefriendly memiliki defenisi sebagai sebuah kata sifat untuk sebuah situs web yang dapat digunakan pada perangkat seluler seperti tidak memperlambat ponsel, tidak menggulir secara horizontal dalam orientasi vertikal, tidak menggunakan plugin yang tidak tersedia dan dirancang dengan desain halaman situs web yang mempertimbangkan layar perangkat seluler [17].

Google Developers bekerjasama dengan AnswerLab melakukan riset untuk menjawab pertanyaan faktor apa saja yang membuat suatu situs web untuk perangkat seluler dikatakan baik. Riset tersebut diikuti oleh partisipan dari pengguna perangkat seluler di Amerika Serikat dari berbagai platform perangkat seluler. Dari hasil riset yang telah dilakukan, diperoleh 25 prinsip desain situs web khusus untuk perangkat seluler. 25 prinsip desain situs web untuk perangkat seluler dapat dilihat pada tabel 1 .

Tabel 1. Prinsip-prinsip desain situs web untuk perangkat seluler [18]

\section{Prinsip desain} situs web

Poin-poin prinsip desain situs web

\begin{tabular}{|c|c|}
\hline \multirow{4}{*}{$\begin{array}{c}\text { Home Page } \\
\text { and Site } \\
\text { Navigation }\end{array}$} & $\begin{array}{l}\text { 1. Keep calls to action front and } \\
\text { center }\end{array}$ \\
\hline & 2. Keep menus short and sweet \\
\hline & $\begin{array}{l}\text { 3. Make it easy to get back to the } \\
\text { home page }\end{array}$ \\
\hline & $\begin{array}{l}\text { 4. Don't let promotions steal the } \\
\text { show }\end{array}$ \\
\hline \multirow{4}{*}{ Site Search } & 1. Make site search visible \\
\hline & 2. Ensure site search result relevan \\
\hline & $\begin{array}{l}\text { 3. Implement filters to narrow } \\
\text { result }\end{array}$ \\
\hline & $\begin{array}{l}\text { 4. Guide user to better site search } \\
\text { result }\end{array}$ \\
\hline \multirow{5}{*}{$\begin{array}{l}\text { Commerce } \\
\text { and } \\
\text { Conversion }\end{array}$} & $\begin{array}{l}\text { 1. Let users explore before they } \\
\text { commit }\end{array}$ \\
\hline & 2. Let users purchase as guests \\
\hline & $\begin{array}{l}\text { 3. Use existing information to } \\
\text { maximize convenience }\end{array}$ \\
\hline & $\begin{array}{l}\text { 4. Use click-to-call buttons for } \\
\text { complex tasks }\end{array}$ \\
\hline & $\begin{array}{l}\text { 5. Make it easy to finish on another } \\
\text { device }\end{array}$ \\
\hline \multirow{3}{*}{ Form Entry } & 1. Streamline information entry \\
\hline & 2. Choose the simplest input \\
\hline & de visual calendar fo \\
\hline
\end{tabular}

\begin{tabular}{|c|c|}
\hline & selection \\
\hline & $\begin{array}{l}\text { 4. Minimize from errors with } \\
\text { labeling and real-time validation }\end{array}$ \\
\hline & 5. Design efficient form \\
\hline \multirow{7}{*}{$\begin{array}{l}\text { Usability and } \\
\text { Form Factor }\end{array}$} & $\begin{array}{l}\text { 1. Optimize your entire site for } \\
\text { mobile }\end{array}$ \\
\hline & $\begin{array}{l}\text { 2. Don't make users pinch-to- } \\
\text { zoom }\end{array}$ \\
\hline & $\begin{array}{l}\text { 3. Make product images } \\
\text { expandable }\end{array}$ \\
\hline & $\begin{array}{l}\text { 4. Tell users which orientation } \\
\text { work best }\end{array}$ \\
\hline & $\begin{array}{l}\text { 5. Keep your user in a single } \\
\text { browser window }\end{array}$ \\
\hline & 6. Avoid "full site" labeling \\
\hline & $\begin{array}{l}\text { 7. Be clear why you need a user's } \\
\text { location }\end{array}$ \\
\hline
\end{tabular}

\section{METODE PENELITIAN}

\section{Alur Penelitian}

Alur penelitian dimulai dengan melakukan kajian ulang terhadap penelitian-penelitian yang membahas tentang model evaluasi situs web $E$ Tourism yang telah dilakukan oleh para peneliti sebelumnya. Setelah memilih model evaluasi yang akan dikembangkan, penulis merangkum penelitian yang berkaitan langsung dengan evaluasi dan desain situs web khusus pada perangkat seluler sebagai landasan pengetahuan dalam pengembangan instrumen evaluasi. Kemudian penulis melakukan observasi situs web DMO yang terdapat di Indonesia yang akan dianalisis menggunakan model evaluasi yang telah dikembangkan tersebut.

Setelah instrumen evaluasi disusun, kemudian akan dilakukan validasi terhadap instrumen evaluasi tersebut. Validasi dilakukan oleh ahli dibidang evaluasi sistem informasi. Kriteria ahli yang melakukan validasi adalah seorang akademisi yang memiliki gelar minimal strata dua dan memiliki fokus penelitian dibidang evaluasi sistem informasi. Ahli tersebut kemudian akan memberikan keputusan apakah instrumen tersebut telah layak untuk digunakan, ataupun harus diubah dan mengalami perbaikan.

Jika instrumen evaluasi tersebut telah disetujui oleh ahli, maka instrumen evaluasi tersebut selanjutnya diuji coba untuk mengevaluasi situs web E-Tourism DMO yang dikembangkan oleh Kementrian Pariwisata Republik Indonesia. Berikut alur penelitian dapat dilihat pada Gambar 3.

\section{Sampel Penelitian}

Sampel penelitian ini adalah situs web DMO yang dikembangkan oleh kementrian pariwisata Republik Indonesia yaitu www.indonesia.travel. Situs web tersebut dipilih karena di Indonesia hanya terdapat satu situs web DMO yang mewakili seluruh provinsi yang ada di Indonesia, tidak seperti di Amerika Serikat dan di China yang memiliki situs web DMO pada tiap-tiap provinsinya. Kemudian 
situs web tersebut akan dievaluasi menggunakan model evaluasi ICTRT dengan pengembangan pada evaluasi desain antarmuka pada perangkat seluler. Berikut tampilan situs web www.indonesia.travel dapat dilihat pada gambar 4 .

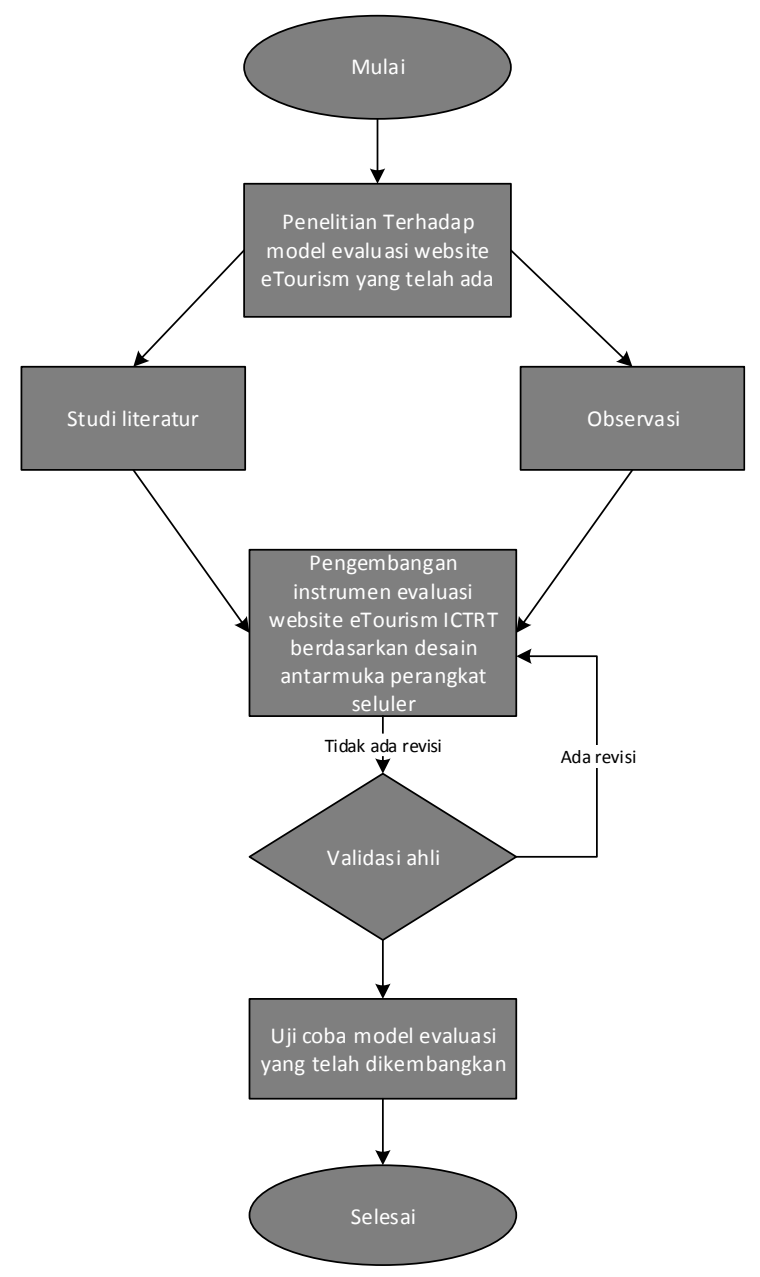

Gambar 3. Alur penelitian

\section{Metode Pengumpulan Data}

Untuk mengevaluasi efektivitas situs web DMO, penulis dibantu oleh narasumber yaitu seorang praktisi IT sekaligus akademisi yang memiliki fokus penelitian di bidang evaluasi sistem informasi. Selanjutnya narasumber memberikan penilaian pada setiap instrumen evaluasi ICTRT yang telah dikembangkan. Penilaian dilakukan dengan cara pemberian bobot nilai pada masingmasing instrumen evaluasi. Nilai yang diberikan pada instrumen tersebut sesuai dengan data yang didapatkan dari hasil analisis instrumen pada situs web yang akan dievaluasi, yaitu situs web www.indonesia.travel.

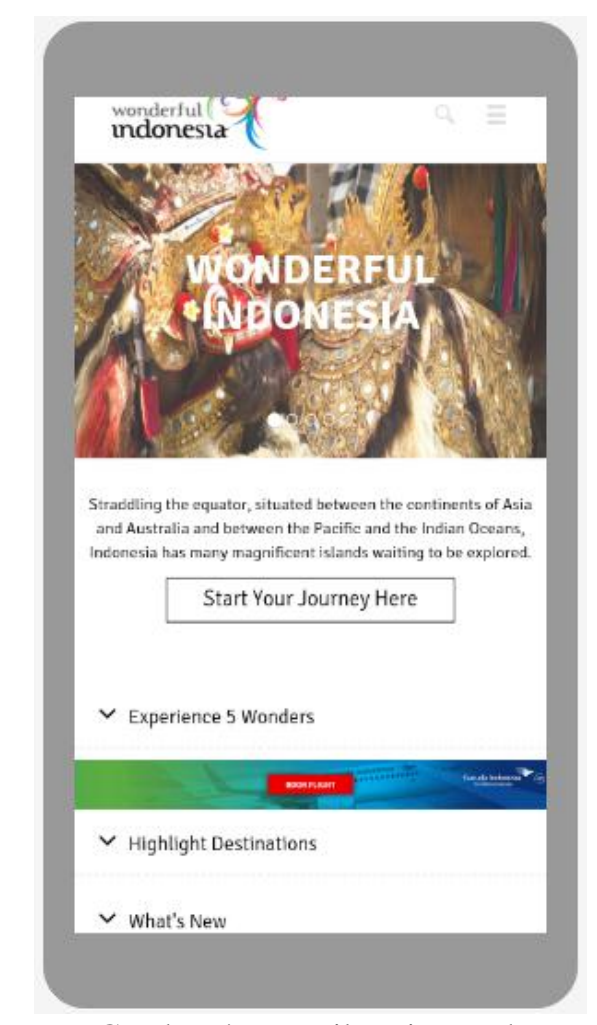

Gambar 4. Tampilan situs web www.indonesia.travel pada perangkat seluler

\section{Metode Analisis Data}

Metode penilaian efektivitas yang digunakan pada model evaluasi ICTRT for mobile mengadopsi penilaian efektivitas yang digunakan dalam penilaian model evaluasi ICTRT. Untuk mendapatkan hasil evaluasi berdasarkan efektivitas situs web DMO, penulis akan menilai performa situs web dengan skala likert dalam skala nilai 5 (1 = sangat buruk, 5 = sangat baik) nilai 0 diberikan jika instrumen tersebut tidak terdapat pada situs web.

Namun, hal itu akan menjadi masalah jika nilai dikumpulkan dan digunakan langsung sebagai ukuran efektivitas situs karena fungsi pemasaran setiap instrumen berbeda. Beberapa instrumen memiliki tingkat kepentingan yang lebih dari instrumen yang lainnya dalam upaya pemasaran tujuan pariwisata. Selain itu, terdapat variasi kompleksitas tiap-tiap teknologi pada aplikasi terkait dengan empat fungsi pemasaran. Item yang lebih penting dengan aplikasi yang rumit harus diberikan nilai lebih dibandingkan dengan item yang kurang penting dan kurang rumit. Sebagai solusi, tingkat kepentingan dan kompleksitas setiap item aplikasi pada situs web juga digunakan dalam mengukur efektivitas situs web.

Penilaian dari tingkat kepentingan instrumen situs web dengan skala likert dalam skala nilai 5 (1 $=$ tidak penting, $5=$ sangat penting). Nilai efektivitas situs web dihitung dengan rumus sebagai berikut:

Efektivitas = performa instrumen $\mathrm{x}$ tingkat kepentingan insturmen 
Setelah didapat nilai efektivitas dari masing-masing dimensi evaluasi, selanjutnya nilai efektivitas dari masing-masing dimensi tersebut akan dibandingkan antara satu dengan yang lainnya.

Tingkat efektivitas dapat dilihat dari nilai yang didapat pada masing-masing dimensi evaluasi, kemudian nilai efektivitas tersebut disederhanakan kembali pada skala 5. Semakin mendekati angka 5 maka dimensi tersebut semakin tinggi nilai efektivitasnya. Sebaliknya jika angka evaluasi dimensi tersebut mendekati angka 0, maka semakin rendah tingkat efektivitasnya. Dengan membandingkan nilai dari tiap dimensi tersebut dapat diidentifikasi dimensi manakah yang memiliki performa kurang maksimal dalam pengembangan situs web DMO, sehingga dimensi tersebut menjadi perhatian yang lebih agar pengaplikasiannya lebih maksimal kedepannya.

Selain menilai tingkat efektivitas situs web, penelitian ini juga akan menilai tingkat kompleksitas dari keempat dimensi evaluasi yang memiliki fungsi pemasaran (dimensi information, communication, transaction dan relationship) dengan skala likert dalam skala nilai $5 \quad(1=$ sangat mudah diimplementasi, $5=$ sangat rumit untuk diimplementasi).

\section{HASIL DAN PEMBAHASAN \\ Perancangan Model Evaluasi}

Tahapan perancangan model evaluasi mencakup proses yang merangkum bagaimana suatu model evaluasi dapat dihasilkan. Metode yang digunakan adalah metode $\mathrm{R} \& \mathrm{D}$ (Reseach and Development) pada tingkat meneliti dan menguji dalam upaya mengembangkan produk/model yang telah ada. Pada penelitian ini penulis mengembangkan model evaluasi yang berbasis pada result model, yaitu model evaluasi yang bertujuan untuk menilai hasil dari sebuah kinerja, program atau organisasi. Penulis mengadopsi model evaluasi ICTRT yang telah dikembangkan oleh peneliti sebelumnya. Model ICTRT terdiri atas 47 instrumen evaluasi dan terbagi pada 5 dimensi evaluasi yaitu information dimension, communication dimension, transaction dimension, relationship dimension dan technical merit dimension yang dapat digunakan untuk mengevaluasi efektivitas situs web DMO.

Dimensi evaluasi ICTRT yang penting untuk dimodifikasi adalah dimensi technical merit. Instrumen pada dimensi tersebut masih menyertakan instrumen teknis penilaian tampilan web pada perangkat komputer konvensional, sehingga perlu dimodifikasi dengan menyertakan instrumen penilaian teknis khusus untuk perangkat seluler. Untuk mengevaluasi tampilan situs web DMO pada perangkat seluler, penulis menganalisa beberapa instrumen pada dimensi technical merit yang harus diganti maupun ditambahkan agar model evaluasi yang akan dikembangkan sesuai dengan kriteria penilaian desain situs web khusus pada perangkat seluler.

Kriteria penilaian yang ditambahkan sesuai dengan hasil studi literatur yang telah dilakukan oleh penulis. Dari hasil studi literatur yang telah dilakukan, penulis merangkum enam instrumen penilaian yang penting untuk menilai desain situs web pada perangkat seluler Berikut instrumen penilaian yang ditambahkan pada model evaluasi ICTRT for mobile dapat dilihat pada tabel 2.

Tabel 2. Instrumen Evaluasi yang di Tambahkan pada dimensi technical merit

\begin{tabular}{|c|c|c|}
\hline No & $\begin{array}{l}\text { Instrumen } \\
\text { Evaluasi yang } \\
\text { Ditambahkan }\end{array}$ & Definisi \\
\hline 1. & Thumbnail & $\begin{array}{l}\text { Penggunaan thumbnail } \\
\text { untuk kategorisasi content } \\
\text { situs web. }\end{array}$ \\
\hline 2. & $\begin{array}{l}\text { Search } \\
\text { function }\end{array}$ & $\begin{array}{l}\text { Tersedia fitur pencarian } \\
\text { langsung berdasarkan } \\
\text { kategori informasi tertentu } \\
{[9]}\end{array}$ \\
\hline 3. & $\begin{array}{l}\text { Mobile } \\
\text { navigation }\end{array}$ & $\begin{array}{l}\text { Pengurangan kegiatan } \\
\text { scrolling halaman situs } \\
\text { web, meletakkan fitur } \\
\text { navigasi menu yang } \\
\text { bersifat tetap pada bagian } \\
\text { atas/samping halaman situs } \\
\text { web [9] dan menggunakan } \\
\text { panduan desain navigasi } \\
\text { khusus untuk perangkat } \\
\text { seluler }\end{array}$ \\
\hline 4. & $\begin{array}{l}\text { Web page } \\
\text { responsiveness }\end{array}$ & $\begin{array}{l}\text { Halaman situs web } \\
\text { responsif dan dapat dibuka } \\
\text { menyesuaikan ukuran layar } \\
\text { perangkat seluler. }\end{array}$ \\
\hline 5. & Form entry & $\begin{array}{l}\text { Desain form yang sesuai } \\
\text { untuk tampilan situs web } \\
\text { pada perangkat seluler. }\end{array}$ \\
\hline 6. & $\begin{array}{l}\text { Usability } \quad \& \\
\text { form factor }\end{array}$ & $\begin{array}{l}\text { Memperhatikan hal-hal } \\
\text { yang berkaitan dengan } \\
\text { usability situs web pada } \\
\text { perangkat seuler. }\end{array}$ \\
\hline
\end{tabular}

\section{Hasil Validasi Ahli}

Dari hasil diskusi penulis dengan ahli, selanjutnya instrumen webpage design dan navigation dihapus dari kriteria penilaian, karena penilaian instrumen webpage design telah digantikan dengan instrumen penilaian usability and form factor dan web page responsiveness, sementara instrumen navigation diganti dengan instrumen mobile navigation yang lebih tepat untuk menilai teknis desain pada perangkat seluler.

Instrumen search function yang terdapat pada dimensi communication dipindahkan pada dimensi technical merit, karena instrumen search function menjadi lebih teknis dan rumit dalam penerapannya untuk mendukung kemudahan untuk perangkat 
seluler. Pada dimensi information, instrumen virtual tour tidak digunakan karena tidak sesuai dengan kebutuhan situs web pada perangkat seluler. Pada dimensi ini ditambahkan instrumen visa information. Instrumen tersebut berisi informasi mengenai penggunaan visa di Indonesia yang penting untuk diketahui oleh wisatawan luar negeri yang ingin berwisata di Indonesia.

\section{Pengujian Evaluasi situs web DMO}

Setelah model evaluasi telah divalidasi oleh ahli, selanjutnya model tersebut digunakan untuk mengevaluasi situs web DMO. Berikut hasil evaluasi efektivitas situs web DMO www.indonesia.travel menggunakan model evaluasi ICTRT yang telah dikembangkan, dapat dilihat pada Tabel 3.

\section{Perbandingan Efektifitas Antar Dimensi Evaluasi

Hasil evaluasi situs web DMO
www.indonesia.travel menampilkan efektivitas yang beragam pada masing-masing instrumennya telah dipaparkan pada Tabel 3 Dari analisis yang telah dilakukan terhadap dimensi information, transaction, communication, relationship dan technical merit, diperoleh hasil dimensi technical merit memiliki tingkat efektivitas tertinggi dengan nilai rata-rata 18,64 .

Dimensi dengan tingkat terendah dimiliki oleh dimensi relationship dengan nilai efektivitas 0 .

Pada dimensi information, instrumen dengan tingkat efektivitas tertinggi diperoleh oleh atribut activities information, attraction information, visitor center information dan visa and immigration information dengan nilai 25. Beberapa instrumen evaluasi pada dimensi ini memiliki nilai 0 karena belum diadopsi pada situs web www.indonesia.travel, diantaranya adalah instrumen travel packages, tavel guides/brochure, information by market segment dan local weather information. Dimensi ini memiliki tingkat efektivitas tertinggi kedua setelah dimensi technical merit dengan nilai rata-rata efektivitas 12,84 .

Dimensi transaction adalah dimensi dengan tingkat efektivitas kedua terendah pada situs web www.indonesia.travel, dengan nilai efektivitas ratarata 2. Pada dimensi ini, hanya terdapat satu instrumen yang memiliki nilai efektivitas, yaitu atribut online reservation dengan nilai efektivitas 10 . Keempat instrumen lainnya yaitu instrumen events tickets, attraction tickets, shopping cart dan web seal certification memiliki nilai efektivitas 0 . Hal ini menunjukkan bahwa situs web www.indonesia.travel belum mengedepankan fitur transaksi melalui layanan online.

Pada dimensi communication, instrumen dengan tingkat efektivitas tertinggi diperoleh oleh atribut atribut multiple language function dengan nilai 25, kemudian diikuti oleh atribut contact information,multiple language versions dan links to social media dengan nilai efektivitas 20. Instrumen dengan nilai terendah diperoleh pada beberapa atribut yang memiliki nilai efektivitas 0 , yaitu brochure request capabilities, feedback forms, surveys dan frequently asked questions. Dimensi ini memiliki nilai efektivitas tertinggi ketiga, dengan total rata-rata nilai efektivitas 11,11 .

Dimensi relationship pada situs web www.indonesia.travel berada pada peringkat terakhir dengan nilai rata-rata efektivitas pada tiap instrumennya bernilai 0 . Hasil evaluasi pada dimensi ini membuktikan bahwa terdapat hubungan yang erat antara dimensi transaction dan dimensi relationship. Rendahnya efektivitas pada dimensi transaction yang mengindikasikan bahwa situs web www.indonesia.travel belum memaksimalkan penawaran transaksi secara online, mencerminkan bahwa dimensi relationship juga akan memperoleh nilai efektivitas yang rendah pula. Hal tersebut dikarenakan dimensi relationship berperan untuk memaksimalkan pemasaran produk dan jasa pariwisata yang tersedia pada situs web DMO, sedangkan dimensi transaction berperan untuk menampilkan fitur apa saja yang tersedia untuk menjual produk dan jasa pariwisata yang terdapat pada suatu situs web DMO.

Pada dimensi technical merit seluruh instrumen dinilai sangat penting untuk diimplementasikan pada situs web www.indonesia.travel. Terdapat tiga instrumen yang memperoleh nilai sempurna pada dimensi ini, yaitu link workability, mobile navigation dan web page responsiveness dengan nilai efektivitas 25 . Instrumen dengan nilai terendah diperoleh oleh atribut site map dengan nilai 0 . Instrumen pada dimensi ini memperoleh nilai efektivitas tertinggi diantara dimensi evaluasi yang lain, dengan total nilai rata-rata efektivitas 18,64.

\section{KESIMPULAN}

Penelitian ini berhasil mengembangkan model evaluasi situs web DMO berdasarkan desain antarmuka perangkat seluler. Model evaluasi tersebut merupakan pengembangan dari model evaluasi ICTRT (Information, Communication, Transaction, Relationship, Technical merit) yang selanjutnya dikembangkan menjadi model evaluasi ICTRT for mobile.

Pada model evaluasi ICTRT for mobile ditambahkan beberapa instrumen penilaian yang dikhususkan untuk menilai desain antarmuka halaman situs web pada perangkat seluler. Total instrumen evaluasi yang digunakan adalah 50 instrumen yang terbagi pada lima dimensi evaluasi.

Model ICTRT for mobile yang telah dikembangkan telah diujikan untuk mengevaluasi situs web DMO www.indonesia.travel. Dari hasil evauasi yang telah dilakukan, diperoleh hasil bahwa efektivitas situs web www.indonesia.travel khususnya pada dimensi transaction dan relationship masih sangat rendah. Dimensi Information dan Communication menunjukkan nilai 
Tabel 3. Hasil penilaian efektivitas situs web DMO www.indonesia.travel menggunakan model evaluasi ICTRT for mobile

\begin{tabular}{|c|c|c|c|c|}
\hline Atribut Situs web & Performa & $\begin{array}{c}\text { Tingkat } \\
\text { Kepentingan }\end{array}$ & Kompleksitas & Efektivitas \\
\hline \multicolumn{5}{|l|}{ Information Dimension } \\
\hline Activities information & 5 & 5 & 5 & 25 \\
\hline Accommodation information & 2 & 5 & 5 & 10 \\
\hline Attraction information & 5 & 5 & 3 & 25 \\
\hline Events calendar & 3 & 5 & 2 & 15 \\
\hline Entertainment information & 1 & 4 & 2 & 4 \\
\hline Maps and directions & 3 & 5 & 5 & 15 \\
\hline Restaurant information & 2 & 4 & 2 & 8 \\
\hline Travel packages & 0 & 0 & 0 & 0 \\
\hline Travel guides/brochures & 0 & 0 & 0 & 0 \\
\hline Transportation information & 3 & 5 & 4 & 15 \\
\hline Photo gallery & 4 & 5 & 2 & 20 \\
\hline Links to regional/city/area pages & 3 & 3 & 1 & 9 \\
\hline Shopping information & 2 & 4 & 2 & 8 \\
\hline $\begin{array}{l}\text { Information by market segment (business, } \\
\text { family, ect) }\end{array}$ & 0 & 0 & 0 & 0 \\
\hline Visitor center information & 5 & 5 & 2 & 25 \\
\hline Travel tips & 5 & 4 & 3 & 20 \\
\hline State facts & 4 & 5 & 2 & 20 \\
\hline Local weather information & 0 & 0 & 0 & 0 \\
\hline Visa and immigration information & 5 & 5 & 2 & 25 \\
\hline
\end{tabular}

Transaction Dimension

\begin{tabular}{l|l|l|l|c} 
Transaction Dimension & 2 & 5 & 5 & 10 \\
\hline Online reservation & 0 & 0 & 0 & 0 \\
Events tickets & 0 & 0 & 0 & 0 \\
Attraction tickets & 0 & 0 & 0 & 0 \\
Shopping carts & 0 & 0 & 0 & 0 \\
Web seal certification & 0 & 0 & 0 \\
\hline
\end{tabular}

Communication Dimension

Contact information (email, phone, mailing address, etc.)

Brochure request capabilities

Destination image communication (logo,

slogan,etc.)

Multiple language versions

Email newsletter

Links to social media (youtube, blog, etc.)

Feedback forms

Surveys

Frequently asked questions

\section{Relationship Dimension}

Privacy policy

Deals and discounts

Personalization

Cross-selling opportunities

Incentive programs/contests

Customer loyalty programs

\begin{tabular}{l|c|c|c|c} 
Customer loyalty programs & 0 & 0 & \multicolumn{2}{c}{0} \\
\hline Technical Merit Dimension & 5 & 5 & $/$ & 25 \\
\hline Link workability & 3 & 5 & $/$ & 15 \\
Load time & 4 & 5 & $/$ & 20 \\
Search engine recognition & 4 & 5 & $/$ & 20 \\
Visual appearance & 0 & 5 & $/$ & 0 \\
Site Map & 5 & 5 & $/$ & 25 \\
Mobile navigation & 5 & 5 & $/$ & 20 \\
Thumbnail & 4 & 5 & $/$ & 20 \\
Search function & 5 & 5 & $/$ & 25 \\
Web page responsiveness & 5 & 5 & 5
\end{tabular}


efektivitas yang cukup, meskipun masih terdapat beberapa fitur masih belum diadopsi. Dimensi technical merit menunjukkan nilai efektivitas yang paling baik diantara dimensi yang lainsnya.

Dengan memperhatikan beberapa dimensi yang mesih menghasilkan efektivitas atribut situs web yang bernilai 0 , pengelola situs web DMO www.indonesia.travel harus memperbaiki dan memberikan perhatian khusus pada atribut tersebut agar fungsional situs web www.indonesia.travel dapat dimanfaatkan semaksimal mungkin.

\section{DAFTAR PUSTAKA}

[1] A. Murtadho and M. R. Shihab, "Anilisis Situs ETourism Indonesia : Studi Terhadap Persebaran Geografis, Pengklasifikasian Situs Serta Pemanfaatan Fungsi dan Fitur," Journal of Information Systems, vol. 7, no. 1, pp. 13-25, 2011

[2] A. M. Morrison, J. S. Taylor and A. Douglas, "Web site evaluation in hospitality and touris: The art is not $P$ yet stated," Journal of Travel \& Tourism Marketing, vol. 17, no. 2/3, pp. 269-293, 2004.

[3] World Tourism Organization, "Survey of destination management organizations," World Tourism Organization, Madrid, Spain, 2004.

[4] S. Schmidt, A. Cantallops and C. dos Santos, "The characteristics of hotel websites and their implications for website effectiveness," International Journal of Hospitality Management, vol. 27, no. 4, pp. 504-516, 2008.

[5] C. Ip, R. Law and H. Lee, "A Review of Website Evaluation Studies in the Tourism and Hospitality Fields from 1996 to 2009," International Journal of Tourism Research, vol. 13, pp. 234-265, 2011.

[6] X. Li and Y. Wang, "Is your official state tourism website effective? A functional perspective," University of Central Florida, 2011.

[7] APJII, "Profil pengguna internet Indonesia 2014," Asosiasi Penyelenggara Jasa Internet Indonesia, Jakarta, 2015.

[8] N. Yu and J. Kong, "User experience with web browsing on small screens: Experimental investigations of mobile-page interface design and homepage design for news websites," Information Sciences, pp. 427-443, 2015.
[9] M. Jones, G. Marsden, N. Mohd-Nasir, K. Boone and G. Buchanan, "Improving Web interaction on small displays," in $W W W$ '99 Proceedings of the eighth international conference on World Wide Web, London, 1999.

[10] W. Peng and Y. Zhou, "The design and research of responsive Web supporting mobile learning device," International Symposium on Educational Technology, pp. 163-167, 2015.

[11] F. C. Lundberg, "Evaluation: definitions, methods and models," ITPS, Östersund, Sweden, 2006.

12] Sugiyono, Metode penelitian \& pengembangan (Research and Development/ R\&D), Bandung: Penerbit Alfabeta, 2015.

13] M. Lu and W. Yeung, "A framework for effective commercial web application development," Internet Research: Electronic Networking Application and Policy, vol. 8, no. 2, pp. 166-173, 1998.

[14] X. Li and Y. Wang, "Measuring the effectiveness of US official state tourism websites," Journal of Vacation Marketing, vol. 17, no. 4, pp. 287-302, 2011.

[15] M. Qiu, K. Zhang and M. Huang, “An Empirical Study of Web Interface Design on Small Display Devices," IEEE/WIC/ACM International Conference on Web Intelligence, 2004.

[16] D. Schubert, "Influence of mobile-friendly design to search results on google search," Procedia - Social and Behavioral Sciences, vol. 220, no. 3, pp. 424433, 2016.

[17] Google Developers, "Glosarium: Google Webmasters," 2016. [Online]. Available: https://developers.google.com/webmasters/mobilesites/glossary. [Accessed 14 September 2016].

,[18] Google \& AnswerLab, "What makes a good mobile site?," Think with Google, 2016. [Online]. Available: https://www.thinkwithgoogle.com/articles/principlesmobile-site-design-delight-users-driveconversions.html. [Accessed 20 November 2016]. 